\title{
Children's Perspective of Game: A Comparison of the Public and Private Schools
}

\author{
Nevin Gündüz ${ }^{1}$, Tuğçe Taşpinar ${ }^{2}$, Nurdan Demiş ${ }^{3}$ \\ ${ }^{1}$ Faculty of Sports Science, Ankara University, Ankara, Turkey \\ ${ }^{2}$ Development Foundation Special Schools, Ankara University, Ankara, Turkey \\ ${ }^{3}$ British Culture College, Ankara, Turkey \\ Correspondence: Nevin Gündüz, Faculty of Sports Science, Ankara University, Ankara, Turkey.
}

Received: July 17, 2017 Accepted: August 14, $2017 \quad$ Online Published: August 17, 2017

doi:10.11114/jets.v5i9.2603 URL: https://doi.org/10.11114/jets.v5i9.2603

\begin{abstract}
The purpose of this research is to determine what the game means from the perspectives of children studying at public and private schools. Four questionnaires were applied to all the third grade parents of four schools; two public and two private schools in Ankara, and questionnaires were completed and sent back by 212 parents. A total of 32 volunteer students from four schools, 4 girls and 4 boys, who were determined according to the results of parents surveys consist of our student research group. Qualitative data were obtained by semi-structured interview technique. Content analysis technique was used for qualitative data and six main themes were created.

As a result, children at private and public schools have described as "the meaning of the play" theme, as "having fun, being happy, having a good time with friends, 'learning new rules, being healthy and doing sports". In the research, they also stated that they play game types such as "rope, hide, hide and seek" which do not require materials in public schools while they indicated they play games such as "ball, dart, taboo and technological games" in private schools. Children indicated that they play at school competitive games prepared by teachers in physical activities lessons. It is concluded that, there is not too much change in the meaning of the game in terms of children who study at private and public schools. Children's type of game and materials especially change for both girls and boys and schools. Although there are purpose of "enjoy" for both of the two groups, but materials and games that used and played are different.
\end{abstract}

Keywords: game, children, public and private school

\section{Introduction}

Game (play) is defined as activities, which are performed freely and voluntarily and which constitute a source of happiness, simulate all development aspects of the child, and develop the senses and emotions as much as improving skills (Pilten et al. 2013). Game is useful for and helps children to develop their physical, emotional, social, intellectual and moral skills, improves their understanding and intelligence, increases their ability to make decisions and generates creativity by providing them to find solutions to the problems that games cause (Driscoll and Negel 2002, Koçyiğit, et al. 2007, Ünal, M., 2009).

Game has an important place in children's life and they can play anywhere (at home, school, park, garden etc.). Active and free play is important in terms of enabling children to socialize and perform physical activity. While Neely, et.al, (2015) describe active and free play as a physical activity spontaneously developing middle and high intensity with little or no adult guidance outside, Lee and Ying-Hua (2015) define it as unstructured physical activities that are played outside in leisure time.

The game is defined as physical or a mental activity that is not performed by force, but is aimed at having fun and enjoying. According to Parry and Archer "There are two levels of play". The first one is to ensure that children stay on the playground and the second is to have contribution to their development in education. It is important that these two are together. (Heseltine and Holborn, 1987) Actually there is no big difference between game and learning. For an adult, playing games can mean fun, but for the child it is like a painful experience. Since at that moment child learns connection with the whole world and catches the secrets of survival (Leccese, 1994). According to Moore and colleagues (1987), "game" is children's way of learning, and in such a process the child develops and socializes. Children's job is playing. 
According to the researches, family attitudes influence emotional aspects of the game. Family also seem to influence children's game choices Koçyiğit et.al. (2007). The other factor influencing game choice is age. School age children prefer mostly regular and social games that are played outdoors. Another child's choice of game is due to the relationship between the choice affecting characteristics and the enjoyment factor, which is the main purpose of the playing (Pilten et.al, 2013). In the framework of this information, the purpose of this research is to determine what the game means from the point of view of children studying at public and private schools. The answers were sought to the following questions in this frame.

1- What does the game mean from the point of view of children who are studying in private and public schools?

2- Have the games that are played by children studying at public and private schools differences?

3- Are playgrounds changing for children who are studying at public and private schools?

4- Are game tools/materials changing in terms of children at public and private schools?

5- Are physical activities and playing classes changing in terms of children at public and private schools?

\section{Method}

Research is a qualitative study that is taken students' opinions.

\subsection{Research Group}

The sample of the study was obtained by easy sampling. Four questionnaires were applied to all the third grade parents of four schools; 2 public and 2 private schools affiliated to National Ministry of Education in Ankara and questionnaires were completed and sent back by 212 parents. A total of 32 volunteer students from four schools, 4 girls and 4 boy, who were determined that they play freely outside the house according to the results of parent surveys consist of our student research group.

\subsection{Data Collection Tool}

In the research, parental information and questionnaire study including four questions were used. In this questionnaire, questions such as whether the children play games or not, what they play with, who they play with and where they play were asked. In the research, questionnaires in which all the questions were answered were taken into consideration. The qualitative data of the study constitutes semi-structured interview questions prepared for 32 volunteer students who we determined according to parent questionnaire opinions. In order to find out the views of children in public and private schools about the meaning of the game and their perspective on the game, a form involving semi-structured interview questions (10 questions) was conducted in the research by compiling studies done in this area. Pilot interviews were performed with three children out of research before the study in order to determine if the questions were clear and understandable. The voice recordings of the interviews were examined by two experts and it was concluded that the questions were appropriate for the purpose. The interview questions we used in the research were created by compiling the studies done in this subject and taking the expert opinions. Qualitative data were obtained by semi-structured interview technique.

\subsection{Collection of Data}

The purpose of the research is clarified to the children and the parents participating in the research and it is explained that participation in the study is completely based on volunteerism. After the completed questionnaire forms were collected, interviews were made with 32 students who requested informed interview about qualitative study. Interviews were made in a closed room on the designated days after students and parents were informed and interviews were conducted using voice recorder. Voice recorder was used during interviews and the duration was between 15- 30 minutes.

Content analysis method which is one of the qualitative analysis methods was used to interpret in an understandable way the data (Yıldırım and Şimşek, 2013), obtained from the answers given by children students participating in face to face interviews. The obtained data were firstly converted into prose form in computer environment and then the data were coded in short sentences with the expressions by the researcher. In the findings of the research, the students' expressions regarding themes are coded as GS1, GS2, BS1, and BS2.

Qualitative Interview Questions:

1- What does the game mean to you? What comes into your mind when you hear the 'game'?

2- Do you play games?

3- Why do you play games? What is your reason for playing?

4- What kind of games do you play? Can you give examples, their names? 
5- Where do you play?

6- What do you play with? With/without material?

7- Who do you play with/ prefer?

8- Do you play at school? At breaks/ at lunch time?

9- Do you play games in your physical education classes?

10- Can you draw a game or a playground in your imagination?

Validity: It has been paid attention that the findings are consistent and meaningful within the study. Obtained findings were ensured that the findings are a whole with the observation by the researcher and the coding expert.

Reliability: The researcher clearly defines the methods and stages of the research. The expressions obtained in the research were coded separately by the researcher and the expert instructor and then the themes were created. The reliability analysis of the qualitative data was calculated by the formula developed by Miles and Huberman (1984) and the reliability was found $\% 88$.

$$
\mathrm{P}(\text { reliability percentage })=\frac{\mathrm{Na}(\text { Agreement })}{\mathrm{Na}(\text { Agreement })+\mathrm{Nd} \text { (Divergence) }} \times 100
$$

Table 1. Distribution of the Views of Students According to Themes, Codes and Subjects

\begin{tabular}{lll}
\hline SAMPLE EXCERPT & CODE & THEMES \\
\hline $\begin{array}{l}\text { Having fun, Joy, Happiness, Doing fun things, Freedom, Having fun } \\
\text { when bored }\end{array}$ & Affective Development & \\
To learn, To train myself, To learn new games and rules & Cognitive Development & $\begin{array}{l}\text { The Meaning of the } \\
\text { Game }\end{array}$
\end{tabular}

To build better relationships with my friends,

Meeting and playing with them

Being healthy, Losing weight, Blowing off the steam. It's both fun and letting up problems

Social Development

High above the ground, Playing tag,

Physical Development

Played games Game Types

Skipping rope, Blind man's bluff,

Hide and seek, Dodge ball,

Playing house, Dombik

I frequently play at breaks and lunch.

Game at School

People Playing together

Game Materials

Game at Physical activities and playing class
Game at School

Game Friends

Game Tools

Physical activities and playing class

Yes. Football, basketball, volleyball, fish net, mud man, such things. Technological games

Codification of the Data: After interview texts were read line by line, the codes that are found important by the researcher were highlighted.

Finding Themes: After the coding process was over, appropriate themes were formed by associating codes related to each other. Thematic coding is to categorize (theme) pre-determined codes by detecting common aspects.

\subsection{Analysis of the Data}

Descriptive statistics were used in the analysis of the quantitative data in the study, and the results were interpreted in the tables with frequency percentages and averages. In the qualitative study, the content analysis technique was used in the evaluation of the interview questions, the interviews were first coded separately by the researchers and six main themes were formed classifying interviews under certain themes. "The meaning of the game" theme has subsumed under four sub-themes.

\section{Themes:}

1- The Meaning of the Game

-Affective Development

-Cognitive Development
-Social Development

-Physical Development 


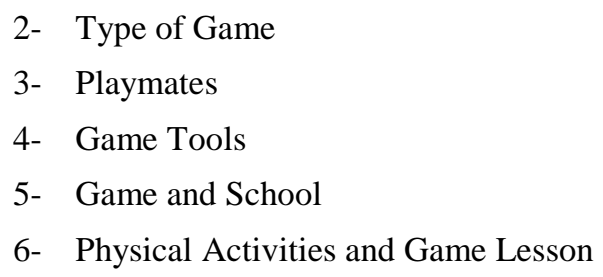

\section{Findings}

Table 2. Distribution of Children's Playing Games According to Parents

\begin{tabular}{lllll}
\hline & Private School & \multicolumn{3}{c}{ State School } \\
\hline Answers & F & $\%$ & F & $\%$ \\
Yes & 82 & 100,0 & 130 & 100,0 \\
No & 0 & 0 & 0 & 0 \\
\hline
\end{tabular}

All of the private and state school children in the research play games according to the views of parents.

Table 3. Distribution of Types of Play According to Parents

\begin{tabular}{lccll}
\hline & & Private School & \multicolumn{2}{l}{ State School } \\
\hline Answers & $\mathrm{f}$ & $\%$ & $\mathrm{f}$ & $\%$ \\
Video games & 14 & 17,1 & 13 & 10,0 \\
Toys & 31 & 37,8 & 63 & 48,5 \\
Activities/sports & 37 & 45,1 & 54 & 41,5 \\
Total & 82 & 100,0 & 130 & 100,0
\end{tabular}

The parents in the research stated that the types of games mostly played by private school children were activities and various forms of sports but state school children played with toys.

Table 4. Distribution the Places of Play According To Parents.

\begin{tabular}{lccll}
\hline & & Private School & \multicolumn{2}{l}{ State School } \\
\hline Answers & $\mathrm{F}$ & $\%$ & $\mathrm{~F}$ & $\%$ \\
At Home & 24 & 29,3 & 42 & 32,3 \\
In the Garden & 19 & 23,2 & 29 & 22,3 \\
In Playgrounds & 14 & 17,1 & 28 & 21,5 \\
At School & 17 & 20,7 & 26 & 20,0 \\
Other & 8 & 9,8 & 5 & 3,8 \\
Total & 82 & 100,0 & 130 & 100,0 \\
\hline
\end{tabular}

The parents in the research stated that the places, where private and state school children play games, were mostly; at home, in the garden, at school, and in the playgrounds.

Table 5. Children Play Games with Whom According To Parents.

\begin{tabular}{|c|c|c|c|c|c|}
\hline \multirow[b]{2}{*}{ Answers } & & \multicolumn{2}{|c|}{ Private School } & \multicolumn{2}{|c|}{ State School } \\
\hline & & $\mathrm{F}$ & $\%$ & $\mathrm{f}$ & $\%$ \\
\hline Alone & & 9 & 11,0 & 18 & 13,8 \\
\hline With friends & & 40 & 48,8 & 62 & 47,7 \\
\hline $\begin{array}{l}\text { Younger and } \\
\text { brothers }\end{array}$ & older & 19 & 23,2 & 44 & 33,8 \\
\hline Other & & 14 & 17,1 & 6 & 4,6 \\
\hline Total & & 82 & 100,0 & 130 & 100,0 \\
\hline
\end{tabular}

The parents in the research stated that both private and state school children mostly played with their friends. 
Table 6. The Meaning of Game

\begin{tabular}{|c|c|c|c|}
\hline Students & Sub-Theme & Public School & Private School \\
\hline Female & $\begin{array}{l}\text { Affective } \\
\text { Development }\end{array}$ & $\begin{array}{l}\text { Having fun, Joy, Happiness, Doing fun } \\
\text { things, Blowing off the steam. } \\
\text { It's both fun and letting up problems }\end{array}$ & $\begin{array}{l}\text { Being happy, Joy , Excitement, } \\
\text { Freedom, Relaxing, } \\
\text { Learning to lose and having fun }\end{array}$ \\
\hline Male & $\begin{array}{l}\text { Affective } \\
\text { Development }\end{array}$ & $\begin{array}{l}\text { Having fun, } \\
\text { Happiness }\end{array}$ & $\begin{array}{l}\text { Freedom, Having fun, A beautiful } \\
\text { thing, Happiness, Joy }\end{array}$ \\
\hline Female & $\begin{array}{l}\text { Social } \\
\text { Development }\end{array}$ & - & $\begin{array}{l}\text { Meeting my friends and playing with } \\
\text { them }\end{array}$ \\
\hline Male & $\begin{array}{l}\text { Social } \\
\text { Development }\end{array}$ & To build better relationships with my friends & Having a good time with my friends \\
\hline Female & $\begin{array}{l}\text { Cognitive } \\
\text { Development }\end{array}$ & - & $\begin{array}{l}\text { Learning, Learning new games and } \\
\text { rules }\end{array}$ \\
\hline Male & $\begin{array}{l}\text { Cognitive } \\
\text { Development }\end{array}$ & 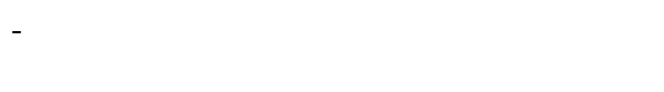 & $\begin{array}{l}\text { To educate myself, } \\
\text { Spending time }\end{array}$ \\
\hline Female & $\begin{array}{l}\text { Physical } \\
\text { Development }\end{array}$ & Losing weight, Doing sports & - \\
\hline Male & $\begin{array}{l}\text { Physical } \\
\text { Development }\end{array}$ & $\begin{array}{l}\text { Health, Being healthy } \\
\text { Doing sports, Losing weight }\end{array}$ & Doing sports \\
\hline \multicolumn{4}{|c|}{$\begin{array}{l}\text { In the research, children studying at private and public schools have similarly described the theme of "Affective } \\
\text { Development", which is the first sub-theme of "The Meaning of Game" theme, as "having fun, being happy, excitement, } \\
\text { freedom, joy and blowing off steam". In the sub-theme of "Social Development", students-except for girl students at public } \\
\text { schools- have similar interpretations as "having a good time with my friends, meeting my friends and playing with them". In } \\
\text { the sub-theme of "Cognitive Development", only children at private schools interpreted as "'learning new rules, educating } \\
\text { oneself". In the sub-theme of "Physical Development", the students stated that "losing weight, doing sports, being healthy". }\end{array}$} \\
\hline
\end{tabular}

Table 7. Type of Game

\begin{tabular}{lll}
\hline Students & Public School & Private School \\
\hline Female & Skipping rope, Playing tag, & Various spores, technological games, Hopscotch, \\
& Hide and seek, Dodge ball, Playing house, & Skipping rope, Hide and seek, High above the ground, \\
& Dombik, & Playing tag
\end{tabular}

In the research, while game types of children at public schools: are games which do not require materials such as skipping rope, playing tag, swinging, playing house, and dombik, the children at private schools stated that they play games which require materials and are specific branches such as "technological games, high above the ground, dart game, football, and basketball" in addition to similar games as mentioned above.

Table 8. Playmates

\begin{tabular}{lll}
\hline Students & Public School & Private School \\
\hline Female & With my friends, With my family & $\begin{array}{l}\text { With my mother, father, cousins, classmates, siblings, on } \\
\text { my own }\end{array}$ \\
Male & $\begin{array}{c}\text { With my friends, With one of my family } \\
\text { members }\end{array}$ & $\begin{array}{c}\text { With my mother, father, cousins, classmates, siblings, } \\
\text { friends }\end{array}$ \\
\hline
\end{tabular}

Children at private and public schools indicated in the research that they play with 'friends, family, siblings, and cousins".

Table 9. Game Tools

\begin{tabular}{lll}
\hline Students & Public School & Private School \\
\hline Female & Ball, Rope, Dolls, Hula hoop & Ball, Rope, Toys, Dolls \\
Male & Ball, Rope, Tablet computer & X-Box 360, Ball, Stick, Computer, Toys, Dart, Target Board \\
\hline
\end{tabular}

Children in public schools play with tools such as "rope, ball, doll, hula hoop, tablet computer" in the research, while children in private schools stated that they play with tools like "technological toys, darts, target boards" as well as the game tools mentioned above. 
Table 10. School and Game

\begin{tabular}{lll}
\hline Students & Public School & Private School \\
\hline Female & I play at breaks and lunch times. & I play at breaks and lunch times. \\
Male & I play at breaks and lunch times. & I play at breaks and lunch times. \\
\hline
\end{tabular}

Children at public and private schools have indicated in the research that they play games during the breaks and lunch times in the school.

Table 11. Physical Activities Game Lessons

\begin{tabular}{|c|c|c|}
\hline Students & Public School & Private School \\
\hline Female & $\begin{array}{l}\text { Yes I play, the teacher makes us play fun } \\
\text { competition games, and we play games that } \\
\text { everybody wants. }\end{array}$ & $\begin{array}{l}\text { Yes I play, the teacher makes us play his/her own } \\
\text { games, we play on the playground prepared by the } \\
\text { teacher, and we play games that we choose. }\end{array}$ \\
\hline Male & $\begin{array}{l}\text { Yes I play, the teacher makes us play fun games, } \\
\text { sometimes we play what the teacher wants and } \\
\text { sometimes we play games that everybody wants. }\end{array}$ & $\begin{array}{l}\text { Yes I play; games that we choose on our own, the } \\
\text { teacher sometimes releases us after warming up, and } \\
\text { we play on the playground prepared by the teacher. }\end{array}$ \\
\hline
\end{tabular}

In the research, while children in public schools have indicated that they play in physical activities and playing lessons, their teachers make fun competitions and sometimes they play games that everybody wants, children in private schools likewise have stated that they play on the playgrounds prepared by their teachers, sometimes they play the teachers' own games and sometimes the teacher releases them after warming up.

\section{Discussion}

Children at public and private schools have described, in the research, the meaning of the game as 'having fun, being happy, excitement, freedom, joy, and blowing off steam" likewise they have done in the sub-theme of "Affective Development". Miller et al. (2008) stated that children's key criterion in their choice of game is "to have fun" and they often play to have fun. Miller et al. (2008), Bakar et al. (2008), Pilten et al (2013) and Gündüz et al (2017) have indicated in their studies that children play for fun. The game provides important benefits for physical, emotional, social, cognitive, and language development as well as being a pleasurable activity that entertains the child (Bekmezci 2015)

In the sub-theme of "Social Development", students-except for girl children at public schools- have similar interpretations as "having a good time with my friends, meeting my friends and playing with them". Many studies indicate that children's games have social structures, and that they learn easily the rules and necessities of the society during the game. Also, they learn behaviours such as waiting for their turn, sharing, respecting others' and their own right, obeying rules, winning and accepting losing during the game (Driscoll and Negel- 2002, Koçyiğit et al., 2007, Bekmezci 2015).

In the sub-theme "Cognitive Development" in the research, only the children in the private school have interpreted it as "learning new rules, educating themselves". According to Koçyiğit et al. (2007), the game provides children the possibility of researching their environment, in terms of cognitive development, recognizing the objects and problem solving. With this way the child learns many mental processes such as classification, sorting, analysis, synthesis, problem solving and matching many concepts like size, shape, colour, weight, counting, time, distance. Many rules that are hardly taught to the child can be taught more easily during play, and children learn and embrace many rules and concepts, such as learning, decision making, sorting, editing without noticing it (Bekmezci et. al.2015).

In the sub-theme of "'Physical Development", children defined as 'Losing weight, Ding sports, Being healthy". Free and active playing affects children's daily physical activities in total. Furthermore, time spent playing outside is positively associated with moderate physical activity and, conversely, is associated with obesity. Although research on this issue (Glen et al., 2012) emphasizes the consequences of fitness and obesity, social and emotional well-being and cognitive functioning affecting the future happiness of children must also be considered. Lee \& Ying-Hua (2015), playing games allows the child's body systems to function regularly. It is provided that especially the functions related to growing such as burning of excess fat in the body, the strengthening of the muscles, the more regular functioning of the endocrine glands with these games which require the movement of the body (Hekim 2016, Koçyiğit et al., 2007).

In the research, while game types of children studying at public schools: are games which do not require materials such as skipping rope, playing tag, swinging, and playing house, the children at private schools stated that they play games which require materials and are specific branches such as "technological games, high above the ground, dart game, football, and basketball" in addition to similar games as mentioned above. According to Nevin and his colleagues (2017), have been working on the meaning of play with private school students, similar results have been found on the 
type of game they play. According to Koçyiğit et al., (2007) "Family attitudes influence emotional aspects of the game". 'The child reflects in the game environment a lot of emotional attitudes and behaviours from the family'. Socio-cultural factors such as the family also seem to influence children's game choices and shape them accordingly. Children create game perceptions by being influenced by the perspective of the family they are in. According to Flavel, another factor influencing game choice is age. School-age children prefer mostly regular and social games that are played outdoors (Akt: Pilten et al 2013). Pilten et al (2013) stated that the child's choice of game is due to the relationship between the choice-affecting characteristics and the enjoyment factor, which is the main purpose of the playing.

Children in public schools play with tools such as "rope, ball, doll, hula hoop, tablet computer" in the research, while children in private schools stated that they play with tools like "technological toys, darts, target boards" as well as the game tools mentioned above. According to many research, private schools in Turkey also meet the needs of students and teachers on play materials and field. But in state schools can be said materials and equipment are insufficient (Dalkıran et al, 2004, Demirhan et al., 2014, Sunay et al, 2004, Taymaz et al, 2011).

In the research, children who study at private and public school stated that they play games at breaks and lunch time. Glen et al. (2012) stated in the research that children like using construction yards and cottages as play grounds instead of standard designed playing gardens and equipment, tool. Also, research on places where children play indicates that playing in play grounds increases self confidence in children, improves language, communication, social skills, sharing and collaboration as well as lots of physical competence (Driscoll and Negel 2002, Ünal, M., 2009). According to Özdemir et al. 2008, Vural et al. 2016, playgrounds are very important for children's versatile development. School gardens have a significant potential to ensure children's playing and activity needs. However, school gardens need to be designated as physical activity, playgrounds and social spaces, because students use school gardens as playgrounds in breaks, physical education classes and at every opportunity. Studies in this area indicate that the vast majority of the school gardens are made up of asphalt and concretes. Beckwith, (1985) stated that playgrounds are factor affecting the quality of the game and suggested that games should include different experiences, be related, involve group works, be flexible and challenging.

In this research, children in private schools stated that they similarly play track that their teacher prepares, sometimes their teacher make them play their own games, and sometimes teacher releases children after warming-up, while children in public schools stated that they play games in the physical activities lesson and game lesson, teacher makes funny competitions, and sometimes teacher make children play games that everybody wants.

Miller et al, (2008) indicated that children did not approve the activities in lessons as game because of having no fun; activities that kind of competition which requires solving of problems too much are boring. For this reason, they stated that teachers should consider the entertainment concept of the region they work in, so that they should use and organize the educational activities that students can really enjoy. Pilten et al, (2013) showed that socio-economic, cultural, and historical differences between public and private school children differentiate and shape children's game descriptions. Each perceived and shaped the game according to the conditions they are in. Although there are purpose of "enjoy" for both of the two groups, the materials and games that used and played are different.

School garden have a significant potential to meet children's play and activity needs. However, schools gardens need to be organized as physical activity and play facilities, and social places, because children use school gardens as play grounds at physical activity lesson and in every possibility they have (Özdemir et. al.2009, Vural et al. 2016)

As a result, the importance of game for children is known. We can see that there is not too much change in the meaning of the game in terms of children who study at private and public schools, and they can enjoy in some way by playing with a little material in the environment with creativity, however, when we look at cognitive development, we can see the difference of the private school in the course of the physical activities and game lessons with the experts of their area, because these courses are unfortunately carried out within the interest and knowledge of the classroom teachers. Also, tools and equipment were insufficient we can clearly see the differences in practice when we look at the physical possibilities of the public schools (field, equipment-tool). In terms of course work, carrying out of lessons in private schools is better planned and more effective, because the performance of teachers in private schools is more controlled than public school teachers, and creativity of teachers is questioned more by the administrators. This can be noticed by the answers given by children who study in the private school.

\section{Results and Suggestions}

As a result, the importance of game for children is known. There is not too much change in the meaning of the game in terms of children who study at private and public schools. They play game, they often play to have fun and enjoy. For this reason, the classroom teachers should organize this course according to the wishes and needs of the children.

In the sub-theme of cognitive development, there is some change in the meaning of game in terms of children who study 
at private and public school in the course of the physical activities and game lessons with the experts of their area, because these courses are unfortunately carried out within the interest and knowledge of the classroom teachers. For this reason, many rules that are hardly taught to the child more easily during play and children learn many rules and concepts, such as learning, decision making editing without noticing it.

In the sub-theme of social and physical development, there is a no meaning of game in terms of girls who study at public and private schools in the course of the physical activities and game lessons.

In the themes of 'children's type of game and materials' which some of them especially change for girls and boys and schools. In private school many of materials are different for boys such as, technological toys; X-box 360, computer, ball and dart. In private school children have more possibilities about materials than public school children. Socio-economic, cultural, and historical difference between public and private school differentiate children's game descriptions. Although there are purpose of "enjoy" for both of the two groups, but materials and games that used and played are different. For this reason, It is important that similar conditions and facilities (field, equipment-tool) like sports and physical activities are in many private schools should be provided in public schools. Technological toys such as smart mobile devices which popularity is growing fast. These digital devices represent a new generation of technological tools that offer remarkable access to content as well as opportunities for creative use even by young children (Papadakis et. al., 2017). The educational value of those applications is difficult to be determined. Today choosing the most appropriate educational ones for children is difficult and problematic for teachers and this kind of materials are used seldom in the private school also.

Children in both school, play during breaks and lunch time. According to Özdemir et.al.2009, Vural et al. (2016), playgrounds are very important for children's versatile development. School gardens have a significant potential to meet children's play and activity needs. Because children use school gardens as play grounds in breaks, physical education classes and at every opportunity time. Studies in this area indicate that the vast majority of the school gardens are made up of asphalt and concretes. Beckwith (1985) stated that playgrounds are factor affecting the quality of the game and suggested that games should include different experiences, be related, involve group works, be flexible and challenging.

The last themes of "physical activities and the game lesson" children said both teacher makes play and they play freely. According to some research, children did not approve the activities in lessons as game because of having no fun; activities that kind of competition which requires solving of problems too much are boring. For this reason, teachers should consider the entertainment concept of the region they work in, so that they should use the educational activities that students can really enjoy.

\section{References}

Bakar, A., Tuzun, H., \& Cagiltay, H. (2008). Opinions of Students on the Use of Educational Computer Games; Example of Social Studies Course, Hacettepe University Journal of Educational Sciences Faculty, 35, $27-37$.

Beckwith, I., (1985). When Children Play, Association for Childhood Education International us.

Bekmezci, H., \& Ozkan, H. (2015). Effects of Play and Game on Child Health, Izmir Dr. Behcet Uz, Children's Health Hospital Magazine, 5(2), 81-87.

Dalkıran, O., Altıntas, A., Gündüz, N., Sunay, H., \& Akgul, M. (2004). Opinions of Physical Education Teachers in Ankara State University-Private Primary and Secondary Schools on the Efficient Use of Indoor Sports Fields in Extracurricular Activities, Ankara University, Spormetre Journal of Physical Education and Sports Sciences, 2(3), 109-118, September 2004, Ankara.

Demirhan, G., Yeşim, B., Fatma, S., \& Murat, K. (2014). Problems That Physical Education Teachers Encounter in Practice and Their Solution Suggestions, Hacettepe University Journal of Educational Sciences (H. U. Journal of Education), 29(2), 57-68.

Driscoll, A., \& Nagel, N. G. (2002). Early Childhood Education Birth-8, the World of Children, Families and Educators, Boston: Allyn and Bacon.

Glenn, N. M., \& Knight, C. J. (2012). Children's Views About the Meanings of Play, Canada, Well Spring, Vol:23, No:1

Gündüz, N., \& Tuğçe, T. (2017). Determination of What Game Means From Children's Point of View, Occupational Medicine and Health Affairs, 5(1). https://doi.org/10.4172/2329-6879.1000258

Hekim, M. (2016). Evaluation of the effects of participation in physical education, sport and play activities on bone development in children. Gümüşhane University Journal of Health Sciences, 5(2), 66-71.

Heseltine, P., \& Holborn, J. (1987). Playgrounds: the Planning and Construction of Game Environments. London: The Mitchell Pub. Co. Ltd.

Koçyiğit, S., Tuğluk, M. N., \& Kök, M. (2007). Game as an Educational Event in the Development Process of the Child. 
Atatürk University, Kazım Karabekir Journal of Educational Sciences, 16, 325-342.

Leccese, M. (1994). Landscape Arclitiecture, 84(9), September, 'Recreation Centre. Frederick A, Praegers Publishers, US

Lee, Y. H. (2015). Playfulness toward Active Free Play among School - Age Children.

Miles, M. B., \& Huberman, A. M. (1994). Qualitative Data Analysis, $2^{\text {nd }}$ Ed., Newbury Park, CA: Sage.

Miller, E., \& Kuhaneck, H. (2008). Children's Perceptions of Play Experience and the Development of Play Preferences, a Qualitative Study, American Journal of Occupational Therapy, 62, 407-415. https://doi.org/10.5014/ajot.62.4.407

Moore, R. C., Glotsman, S. M., \& Lacofone, D. S. (1987). Play for All Guidelines Planning designing, Management of Outdoor Play Setting for All Children-MIG Communications Barkley, C.A., US

Neely, C. K., Ingstrup, M., Pynn, S., \& Holt, L. N. (2015). What Grandparents, Parents, And Kids Say About Play!, Well Spring, No: 1.

Özdemir, A., \& Yilmaz, O. (2008). Assessment of Outdoor School Environments and Physical Activity in Ankara's Primary Schools. Journal of Environmental Psychology, 28(3), 287-300. https://doi.org/10.1016/j.jenvp.2008.02.004

Papadakis, S., \& Kalogiannakis, M. (2017). Mobile Educational Applications For Children: What Educators And Parents Need To Know, International Journal of Mobile Learning and Organization (Special Issue on Mobile Learning Application and Strategies), 11(3), 257-277. https://doi.org/10.1504/IJMLO.2017.085338

Pilten, P., \& Pilten, G. (2013). Assessment of Perceptions and Game Preferences of School Children on Game Concept. Journal of Mersin University Education Faculty 9, 15-31.

Sönmez, T., \& Sunay, H. (2004). A study on the problems of physical education and sports lessons applied in secondary schools in Ankara. National Education Magazine, 32(162), 270-277.

Taymaz, H. (2011). Investigation of Occupational Problems of Physical Education and Sports Teachers in State and Private Primary Schools, Master's Thesis, Mehmet Akif Ersoy University, Burdur.

Vural, H., \& Y1lmaz, H. (2016). Evaluation of the Effect of Improved Physical Environment Conditions on the Development of Students by the Eyes of the Teacher, Bayburt University Journal of Educational Sciences, Book: 11(2), 518-533.

Yıldırım, A., \& Şimşek, H. (2013). Qualitative Study Methods in Social Sciences,(9. Extended Edition), Seçkin Publisher, Ankara.

\section{Copyrights}

Copyright for this article is retained by the author(s), with first publication rights granted to the journal.

This is an open-access article distributed under the terms and conditions of the Creative Commons Attribution license which permits unrestricted use, distribution, and reproduction in any medium, provided the original work is properly cited. 